\title{
The Mesozoic-Cenozoic tectonic evolution of the New Siberian Islands, NE Russia
}

\author{
CHRISTIAN BRANDES* $\dagger$, KARSTEN PIEPJOHN $\ddagger$, DIETER FRANKE $\ddagger$, \\ NIKOLAY SOBOLEV \& \& CHRISTOPH GAEDICKE $\ddagger$ \\ *Institut für Geologie, Leibniz Universität Hannover, Callinstraße, 30167 Hannover, Germany \\ $\ddagger$ Bundesanstalt für Geowissenschaften und Rohstoffe (BGR), Stilleweg 2, 30655 Hannover, Germany \\ §A.P. Karpinsky Russian Geological Research Institute (VSEGEI), Sredny av. 74, 199106 Saint-Petersburg, Russia
}

(Received 27 December 2013; accepted 4 June 2014; first published online 25 September 2014)

\begin{abstract}
On the New Siberian Islands the rocks of the east Russian Arctic shelf are exposed and allow an assessment of the structural evolution of the region. Tectonic fabrics provide evidence of three palaeo-shortening directions (NE-SW, WNW-ESE and NNW-SSE to NNE-SSW) and one set of palaeo-extension directions revealed a NE-SW to NNE-SSW direction. The contractional deformation is most likely the expression of the Cretaceous formation of the South Anyui fold-thrust belt. The NE-SW shortening is the most prominent tectonic phase in the study area. The WNW-ESE and NNW-SSE to NNE-SSW-oriented palaeo-shortening directions are also most likely related to fold belt formation; the latter might also have resulted from a bend in the suture zone. The younger Cenozoic NE-SW to NNE-SSW extensional direction is interpreted as a consequence of rifting in the Laptev Sea.
\end{abstract}

Keywords: New Siberian Islands, De Long Islands, South Anyui suture zone, fold-thrust belt.

\section{Introduction}

In the last decades, several plate tectonic models have been developed to explain the evolution of the Arctic region (e.g. Jones, 1980; Rowley \& Lottes, 1988; Miller et al. 2006; Shepard, Müller \& Seton, 2013; Vernikovsky et al. 2013a), but there are still many open questions. Little is known so far about the structural evolution of the New Siberian Islands, which are located in a key position on the east Russian Arctic shelf between the Laptev and the East Siberian seas (Fig. 1). This area is the western margin of the AlaskaChukotka microplate (e.g. Miller et al. 2006) and its structural evolution is important for understanding the Mesozoic-Cenozoic tectonic evolution of the Arctic region (Vernikovsky et al. 2013b). Studies have focused on the tectonics of the Laptev Sea region (Fujita, Cambray \& Velbel, 1990; Drachev et al. 1998). Current models largely depend on offshore reflection seismics (Drachev et al. 1998; Franke, Hinz \& Oncken, 2001; Franke \& Hinz, 2005, 2009). The onshore structural evolution of the New Siberian Islands has only been analysed at selected locations (e.g. Kos'ko \& Trufanov, 2002; Kuzmichev \& Pease, 2007; Kuzmichev, 2009) and knowledge is limited. There are no recent datasets from the De Long Islands available. To close this gap, we present results of an onshore field-based structural analysis carried out during the Circum-Arctic Structural Events (CASE) 13 expedition in 2011, covering large parts of the New Siberian Islands including the De Long Islands.

The palaeo-shortening and palaeo-extension directions were derived from the trend of fold-axes and fault-

$\nmid$ †uthor for correspondence: brandes@geowi.uni-hannover.de slip data. Such datasets deliver important information for understanding the regional geodynamic evolution of the study area. In addition, understanding the orientation of faults and fractures is also important for hydrocarbon exploration (Gohram et al. 1979; Narr 1991; Hennings, Olson \& Thompson, 2000; Zahm \& Hennings, 2009) and drilling campaigns (Dusseault et al. 2004). The Laptev and East Siberian seas are regarded as an important hydrocarbon province (e.g. Cramer \& Franke, 2005; Khain, Polyakova \& Filtova, 2009). Knowledge about the palaeo-shortening and palaeo-extension directions is crucial for exploration campaigns, because the orientation of natural fractures and faults in sedimentary basins are systematically related to the direction of the regional palaeostress field (Engelder \& Geiser, 1980). Nevertheless, perturbations can occur that modify the local stress field (Homberg et al. 1997). Faults and fractures also have an influence on the subsurface fluid flow properties as they are discontinuities in the rock mass that can affect the vertical and lateral flow (Beaudoin et al. 2011, 2013).

The aims of this study were to: (1) present an analysis of the outcrop-scale brittle fabrics of the New Siberian Islands; (2) derive the directions of tectonic deformation of the eastern Laptev Sea and the western East Siberian Sea; and (3) connect the palaeo-shortening and palaeo-extension directions with the geodynamic evolution of the NE Russian Arctic region.

\section{Geological setting and previous work}

The New Siberian Islands are located between the Laptev Sea and the East Siberian Sea (Fig. 1). They can be divided into three groups: the Lyakhov Islands in the 


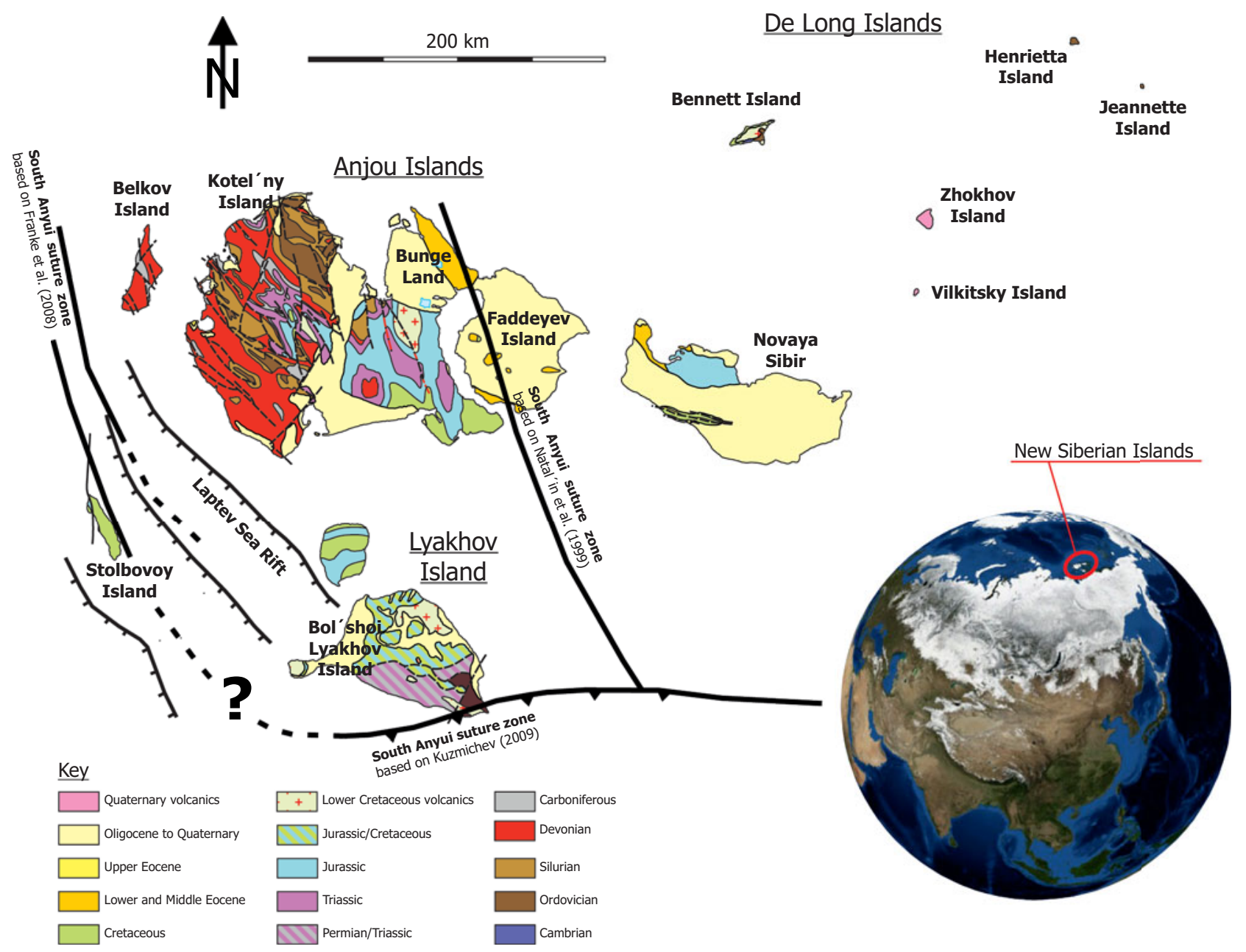

Figure 1. Geological map of the study area. Map is based on VSEGEI, Position of the South Anyui suture zone is modified after Natal'in et al. (1999), Franke et al. (2008) and Kuzmichev (2009). Globe is taken from NASA World Wind.

south; the Anjou Islands in the centre; and the De Long Islands in the northeast (Kos'ko \& Trufanov, 2002). The Lyakhov and Anjou Islands represent a fold-thrust belt that evolved during Jurassic-Cretaceous time and is interpreted to be continuous from NW Alaska over northern Chukotka to the Laptev Sea area (Kos'ko \& Trufanov, 2002; Bondarenko et al. 2003). The New Siberian Islands are regarded as a key area to understand the plate tectonic evolution of the Arctic region and the opening of the Amerasian Basin (Vernikovsky et al. 2013a, b). The offshore geology of the region has been comprehensively analysed over the last 15 years (Franke et al. 1998, 2008; Drachev et al. 1998; Franke, Hinz \& Oncken, 2001; Franke, Hinz \& Reichert, 2004; Drachev, 2011). These studies focused on the geodynamic evolution of the Late Cretaceous - Palaeogene Laptev Sea Rift, based on 2D-seismic reflection lines. The onshore geology of the New Siberian Islands was the subject of different studies dealing with the structural geology of Bol'shoi Lyakhov Island and the nature of the South Anyui suture zone (Kyz'michev et al. 2006; Kuzmichev, 2009). Additional work was carried out on the geochemistry of magmatic rocks of
Belkov Island (Kuzmichev \& Pease, 2007) and on the structural style of parts of Kotel'ny Island and Novaya Sibir (Kos'ko et al. 1990; Kos'ko \& Trufanov, 2002; Kos'ko \& Korago, 2009). These studies were limited in their regional extent however, and there are no recent structural studies available for the De Long Islands. The most recent work on the New Siberian Islands and the De Long Islands has a focus on palaeomagnetics and biostratigraphy (Vernikovsky et al. 2013a,b).

Sedimentary rocks of Cambrian-Cenozoic age are exposed on the New Siberian Islands (Fig. 1). Igneous rocks are also present to a lesser extent. Ordovician rocks are represented by shallow-water carbonates in the northern part of Kotel'ny Island and by deepwater clastics on Bennett and Henrietta Islands. Belkov Island and the SW part of Kotel'ny Island are dominated by Devonian-Carboniferous shales (Fig. 1). TriassicCretaceous rocks are exposed in the central part of Kotel'ny Island. The Cretaceous rocks are widespread on the New Siberian Islands and vary from deepwater clastics (Bol'shoi Lyakhov Island, Stolbovoy Island) to sandstones (central Kotel'ny Island) to sands and soft coals (Novaya Sibir). 

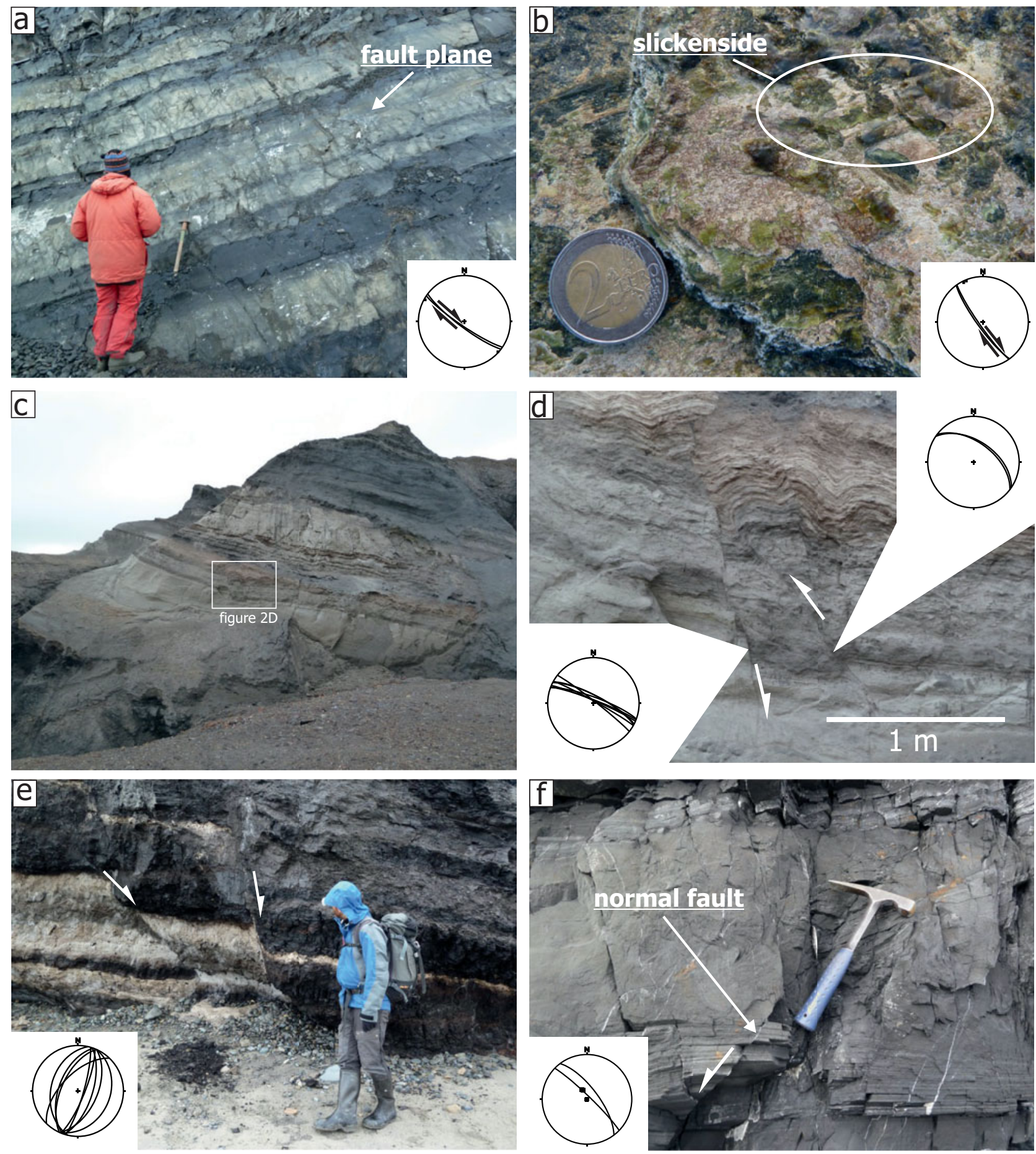

Figure 2. Outcrop photos and stereographic projections from the New Siberian Islands. (a) Strike-slip fault on Stolbovoy Island. The stereographic projection shows the orientation of the fault plane as a great circle and the slickenside striations as dots. (b) Serpentinite with slickenside on Bol'shoi Lyakhov Island. The great circle is the fault plane orientation and the dots indicate the plunge direction of the slickenside striations. (c) Fault-propagation fold on Novaya Sibir. (d) Detail of the fault-propagation fold. The structure was later cut by normal faults. The stereographic projection shows the fault planes as great circles. (e) Normal faults in Palaeogene sediments of northern Bunge Land. (f) Normal faults in Palaeozoic sedimentary rocks on Belkov Island. The stereographic projection shows the fault planes as great circles and the slickenside striations as dots.

\section{Methods}

In more than 40 outcrops across the New Siberian Islands, the orientations of beds, faults and fractures as well as slickensides on these surfaces were measured (Fig. 2). Slickensides are important to derive the direction of movement along individual faults and are the basis for fault-slip analyses. We used the software FaultKin by R. Allmendinger to analyse the fault-slip data and to calculate $P$ and $T$ axes based on the approach of Marrett \& Allmendinger (1990). We derived the directions of palaeo-shortening and palaeo-extension from the $P$ and $T$ axis orientations. 


\section{3.a. Palaeostress field analysis}

Palaeostress field analyses can provide valuable information which can lead to a better understanding of regional tectonic processes and the deformation history of sedimentary basins (Delvaux et al. 1997; Saintot \& Angelier, 2002). Such palaeostress reconstructions reflect the past stresses in the crust for a certain period of deformation, averaged over the duration of a tectonic event (Lacombe, 2012).

Different techniques were developed in the last decades to analyse the orientation of tectonic deformation phases and the related palaeostress field evolution. Hancock \& Kadhi (1978) used conjugate joint sets to derive the horizontal stress trajectories. They showed that conjugate fracture systems that enclose a small dihedral angle probably developed as a consequence of failure in the shear extension fracture transition. This allows the orientation of the three principle stresses, which are referred to as $\sigma_{1}, \sigma_{2}$ and $\sigma_{3}$, to be derived. In such a system $\sigma_{1}$ bisects the smallest dihedral angle and $\sigma_{2}$ is parallel to the intersection of the conjugate fractures. From the orientation of the conjugate fractures, the direction of the three principle stresses can be constrained. Another joint based approach was presented by Engelder \& Geiser (1980) to derive the palaeostress field of the Appalachian Plateau. Parallel to the joint set approach, techniques of fault-slip analysis were developed which are now well established and proven to deliver robust results.

\section{3.a.1. Fault-slip analysis}

Pioneer work on fault-slip analysis was carried out by Angelier \& Mechler (1977). They introduced the socalled right dihedra method that allows the orientation of the principle stresses to be derived graphically from fault-slip data. The key concept of the right dihedra method is the construction of an auxiliary plane that cuts through the fault plane at an angle of $90^{\circ}$ and trends perpendicular to the slip direction. Both planes (fault plane and auxiliary plane) define four quadrants, two compressional and two extensional (Angelier \& Mechler, 1977). The maximum principle stress lies within the pressure quadrant, whereas the minimum principle stress is placed in the tensional quadrant. From the quadrants, the positions of the so-called $P$ and $T$-axes can be derived. The $P$-axis (pressure) and the $T$-axis (tension), also named 'shortening' and 'extension' axes, respectively, lie at $45^{\circ}$ to the fault plane and the auxiliary plane (Fig. 3). They represent the principle axes of the incremental strain tensor of the related fault (Marrett \& Allmendinger, 1990). The intersection of the fault plane and the auxiliary plane is referred to as the $B$-axis. Over the years further techniques were developed for fault-slip analysis, in particular for processing heterogeneous fault-slip datasets (Yamaji, 2000; Zalohar \& Vrabec, 2007; Sato, 2012).

\section{3.a.2. Fracture pattern analysis}

The analysis of fracture pattern associated with folding can provide important information about the evolution of fold structures. Many previous studies have focused on the evolution of fold-related fractures (Harris et al, 1960; Lisle, 1994; Fischer \& Wilkerson, 2000; Bellahsen, Fiore \& Pollard, 2006; Amrouch et al. 2010). Early models such as that of Stearns \& Friedman (1972) describe two conjugate fracture sets referred to as pattern 1 and pattern 2 . Both sets have the common feature that $\sigma_{1}$ and $\sigma_{3}$ are parallel to the bedding plane (Stearns $\&$ Friedman, 1972). The bisecting vector of the acute angle in the conjugate fracture set defines the orientation of $\sigma_{1}$ (Hancock, 1985). In the model of Stearns \& Friedman (1972), the orientation of the conjugate fracture sets varies with the bed trend of the anticline. For the pattern 1, the minimum bisection angle is perpendicular to the outline of the fold. More recent studies developed new fold-fracture models. Bergbauer \& Pollard (2004) showed that fractures formed during folding can be strongly influenced by pre-folding joint sets. Their model described two almost orthogonal pre-folding joint sets. During folding, new joints form parallel to the pre-existing joints on the fold limbs. The hinge area is also characterized by the development of new fractures. None of the syn-folding fractures run parallel or orthogonal to the hinge line (Bergbauer $\&$ Pollard, 2004). Mynatt, Solomon \& Pollard (2009) presented a conceptual model for fracture evolution during folding based on the Raplee Monocline: two sets of pre-folding fractures form an orthogonal pattern, which is overprinted by fracture reactivation and the formation of new fractures during folding. A comparable observation was made by Lacombe, Bellahsen \& Mouthereau (2011) in the Zagros Fold Belt, where pre-/early folding fractures and some syn-folding fractures developed. This shows that fracture development during folding varies over time. Further controlling factors for fracture pattern evolution are the material properties (Mynatt, Solomon \& Pollard, 2009) and the distance to the orogenic front (Beaudoin et al. 2012).

\section{Field data}

\section{4.a. Belkov Island}

Belkov Island is located in the western part of the study area (Fig. 1). The analysed section extends along the SE coastline. Outcrop conditions are good and allow the assessment of sedimentological and structural data. The exposures are dominated by very thin-bedded siltstones and shales, with minor intercalations of thinto medium-bedded, fine-grained sandstones. The siltstones and shales are horizontally laminated, whereas the intercalated sandstone beds often show ripple crossstratification with ripple form sets $(8 \mathrm{~cm}$ from crest to crest) and small-scale flame structures (up to $0.6 \mathrm{~cm}$ high). The depositional ages of the rocks range from Late Devonian to Early Carboniferous (Kuzmichev \& Pease, 2007). They are unconformably overlain by 


\section{exposure in the field}

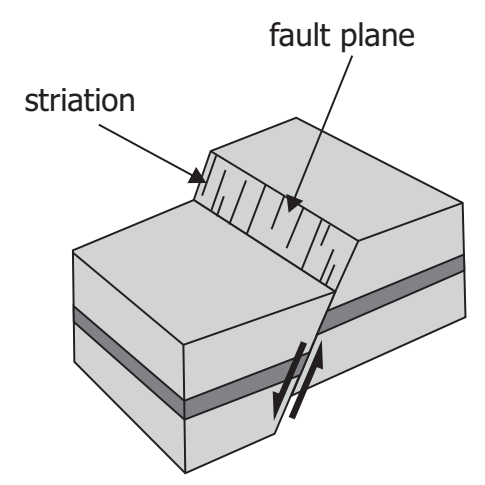

normal fault

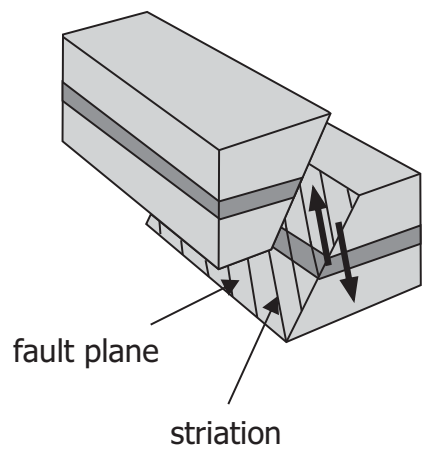

\section{inversion of fault-slip data}
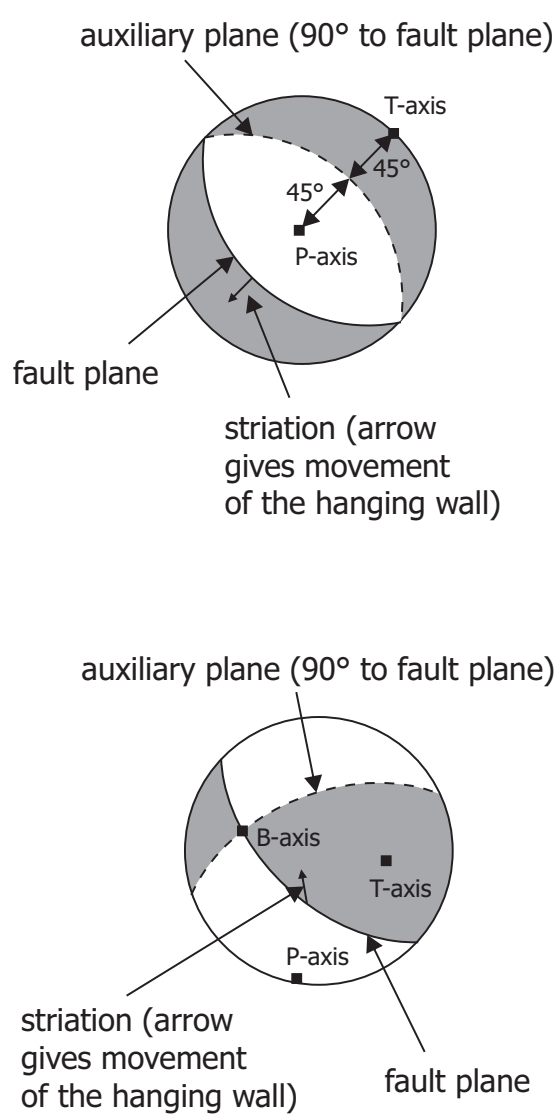

\section{oblique reverse fault}

Figure 3. Concept of fault-slip analysis. The fault plane and the auxiliary plane define four quadrants (two compressional and two extensional). The maximum principle stress lies within the pressure quadrant, whereas the minimum principle stress is placed in the tensional quadrant. From the quadrants, the position of the so-called $P$ - and $T$-axes can be derived. Modified after Berghemer (1990).

unconsolidated Palaeogene sediments. Metre-scale open folds are developed in the Palaeozoic rocks, generally with NW-SE-trending fold axes. Only a minor fold has an east-west-trending axis, reconstructed on the basis of intersection lineations. The shales and siltstones show a pronounced slaty cleavage with cleavage planes steeply dipping towards the NE and SW. The succession is characterized by steeply dipping, NW-SEtrending normal faults (Fig. 2f) and east-west-trending sinistral strike-slip faults. In the northern part of the analysed section, syn-sedimentary normal faults and small (decimetre scale) recumbent folds are developed within the siltstones.

\section{4.b. Kotel'ny Island}

The western and central part of Kotel'ny Island is characterized by large anticlines with NW-SE-trending fold axes. Three different areas of Kotel'ny Island were analysed, the first located at the centre of the island. Due to the low topography, the exposure conditions are very limited and only isolated outcrops occur. Locally sandstone and pebbly sandstones crop out, which are characterized by thin- to medium-bedded sandstones and pebbly sandstones with components of up to $10 \mathrm{~cm}$ in diameter. Some beds have a lenticular shape and show a horizontal stratification or a cross-stratification. The sandstone succession is characterized by coal intercalations. The rocks have an Early Cretaceous age (Aptian-Albian) and belong to the so-called Balyktakh Formation (Kuzmichev, Aleksandrova \& Herman, 2009). Within the sandstone packages, fracture sets are developed with fractures that trend east-west and NNW-SSE.

The second area is located in the NW of Kotel'ny Island, where Devonian-Triassic rocks are exposed. These coastal outcrops are dominated by dark shales which show north-south- and NE-SW-trending fractures. There is evidence for NNE-SSW-trending sinistral strike-slip faults.

The third study area is also at the coast, south of the second location. Ordovician-Devonian sedimentary 
rocks are exposed at this part of Kotel'ny Island, ranging from very thin-bedded shales to very thick-bedded carbonates. Fracture sets dominate, which mainly consist of NNE-SSW- and NW-SE-trending joints. In addition, NW-SE-oriented sinistral strike-slip faults occur.

\section{4.c. Bunge Land}

The analysed section is located at the NE coast and exposes unconsolidated Palaeogene sands and amberbearing soft coal/lignite. Several planar normal faults are developed that dip to the NW and SE. They have offsets in the range of $0.2-1 \mathrm{~m}$ and form conjugate or synthetic patterns (Figs 2e, 4a). In addition, northsouth-trending oblique strike-slip faults and roughly east-west-trending normal faults are developed.

\section{4.d. Stolbovoy Island}

The analysed fabrics on Stolbovoy Island are developed in Lower Cretaceous thin- to very thick-bedded siltstones and fine-grained sandstones, which are interpreted as turbidite sequences (Figs 2a, 4a). Outcrop conditions along the sea cliff are good and allow structural data to be assessed. Large normal faults and strikeslip faults are exposed, which trend north-south and NW-SE, respectively. The north-south-trending strikeslip faults show dextral movements and slickenside, and the NW-SE-trending strike-slip faults indicate sinistral movements.

\section{4.e. Bol'shoi Lyakhov Island}

A wide range of magmatic and metamorphic rocks are exposed on the SE coast of Bol'shoi Lyakhov Island; the outcrops are small and restricted to river valleys and the coastline. Exposed pillow basalts with midocean-ridge basalt (MORB) geochemistry (Kuzmichev, 2009) and related serpentinites (Fig. 2b) are interpreted as remnants of the South Anyui Ocean (Kyz'michev et al. 2006). NW-SE-trending dextral strike-slip faults have developed in the serpentinites. Thrust fault have developed at two locations in the basaltic rocks. The rocks are also characterized by a set of mostly northsouth-trending fractures that can be observed in different outcrops. In addition, WNW-ESE-, ENE-WSWand NE-SW-trending fractures have developed.

\section{4.f. Novaya Sibir}

The analysed section consists of slightly consolidated to unconsolidated Cretaceous (Turonian, age from Herman \& Spicer, 2010) fine-grained sands and lignite. Individual lignite seams reach a thickness of $10 \mathrm{~m}$. The basal part of the section shows a small faultpropagation fold, with a concentric hanging wall anticline (Fig. 2c, d). The dataset derived from the Turonian sediments on Novaya Sibir also shows WNW-ESEtrending reverse faults that are offset by WNW-ESE- trending normal faults (Fig. 2d). Some of the reverse faults could also have been reactivated as normal faults.

\section{4.g. Zhokhov Island}

Zhokhov Island is part of the De Long Island group and it is characterized by Plio-Pleistocene basaltic rocks (Fig. 4a; Bogdanovskii et al. 1992; Silantyev et al. 2004). Observation of outcrops was limited due to widespread snow and ice coverage; however, a set of small WNW-ESE- to east-west-trending normal faults were exposed in one outcrop. The normal faults enclosed a vertical acute angle.

\section{4.h. Henrietta Island}

Ordovician sandstones and volcanic rocks are exposed on Henrietta Island. Observation of outcrops was limited due to widespread snow and ice coverage, but the presence of NE-SW-trending sinistral strike-slip faults was noted; minor NNE-SSW-trending dextral strikeslip faults also occur (Fig. 4a).

\section{4.i. Bennett Island}

Bennett Island is the largest and westernmost island of the De Long group. The analysed section extends along the SE coast and includes Cambrian-Ordovician sedimentary rocks which are overlain by Cretaceous basalt. The sedimentary rocks are sheet-like thin- to medium-bedded mudstones, siltstones and sandstones. The beds are massive or horizontally laminated. The sandstones and siltstones show frequent climbing ripple cross-stratification and pronounced convolute bedding. The bases of the beds are mostly planar, in some cases also erosive. The beds dip towards ENE with low angles between $4^{\circ}$ and $12^{\circ}$. Several vertical NW-SE- and WSW-ENE-trending fracture sets are exposed. The intersection line of the fracture sets in vertical.

\section{Orientations of the tectonic deformation phases}

The most reliable indicators for the tectonic deformation in this study are the trend of anticlinal axes and fault-slip data. From the fault-slip data inversion, the palaeo-shortening and the palaeo-extension directions can be directly derived. Fault-slip data inversion was only possible for faults that showed distinct striations. A map was created based on the dataset, in which the orientation of the major horizontal palaeo-shortening directions are indicated by red arrows and the major horizontal palaeo-extensional direction are given by green arrows (Fig. 4b). Horizontal shortening was the dominant tectonic deformation. The NE-SW-directed palaeo-shortening is the most distinct direction. It can be observed on Stolbovoy, Belkov, Kotel'ny and Henrietta Islands. On Belkov and Kotel'ny Islands in particular, this shortening direction can be derived from the trend of fold axes; the NW-SE-oriented sinistral strike-slip faults on Kotel'ny Island might also belong 


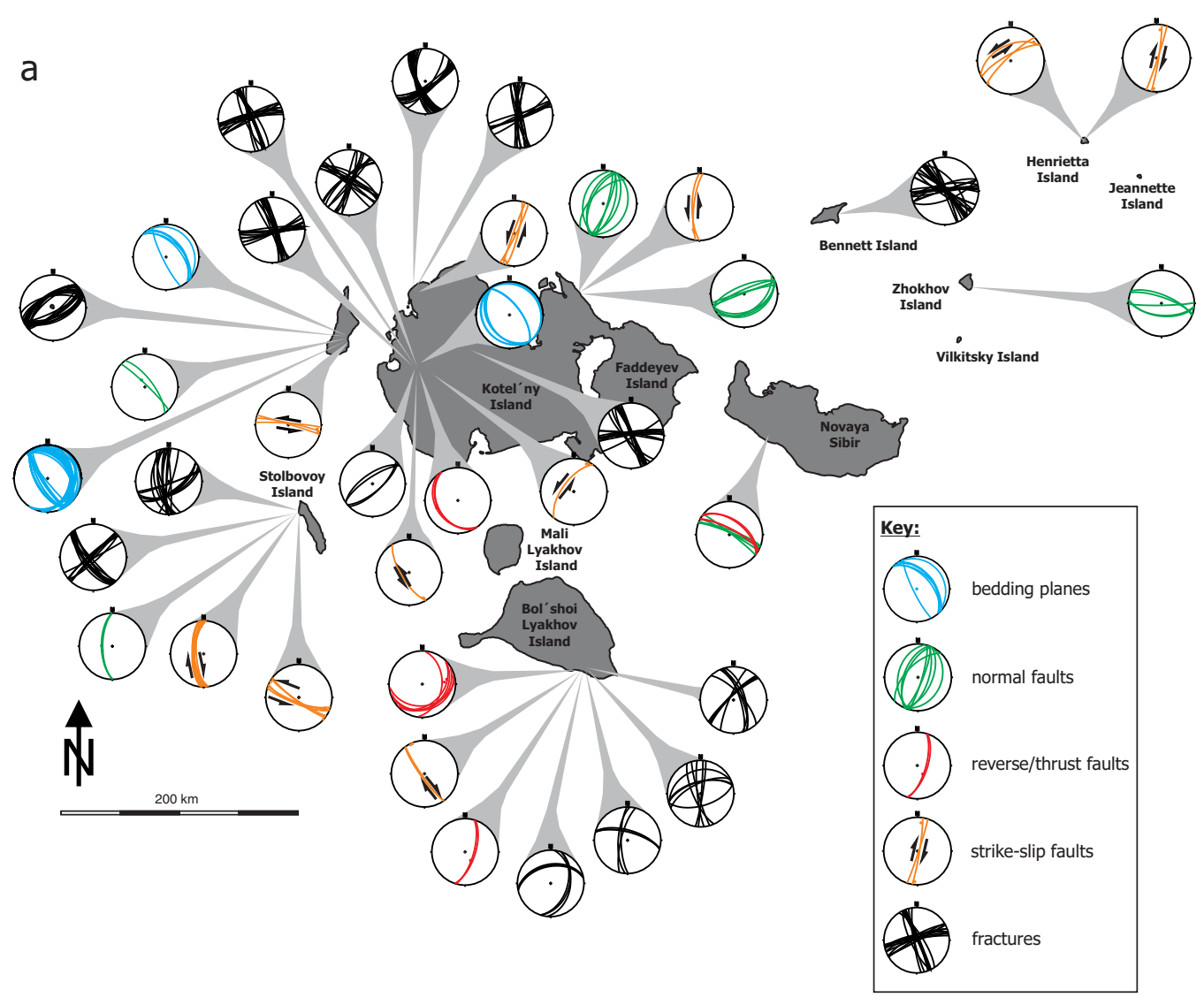

b

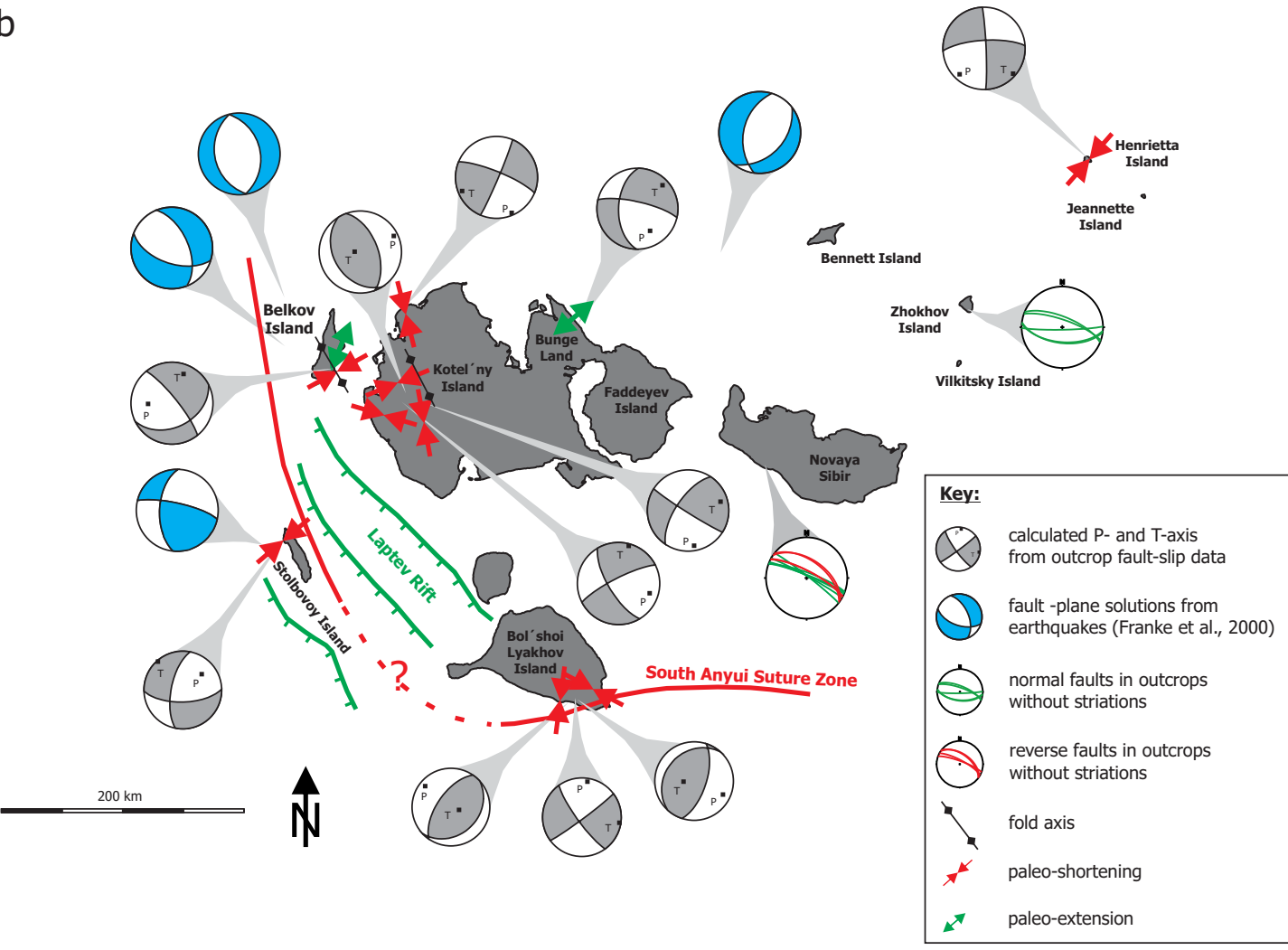

Figure 4. (a) Stereographic projections of the outcrop data. (b) Map of the tectonic deformation. The red arrows indicate the palaeoshortening direction and the green arrows show the direction of palaeo-extension. The shortening direction delineates the trend of the South Anyui suture. The grey fault plane solutions are calculated on the basis of the outcrop data; the blue solutions are derived from earthquakes. 
to this phase. On Stolbovoy and Kotel'ny Islands there is also evidence for a NNW-SSE-directed horizontal shortening. Data from central Kotel'ny Island also give evidence for a WNW-ESE-directed horizontal shortening. On Bol'shoi Lyakhov Island a NNE-SSW-directed horizontal shortening can be observed and there is also evidence for a WNW-ESE-oriented shortening (Fig. 4b).

Data from Belkov Island and northern Bunge Land indicate a NE-SW- to NNE-SSW- directed horizontal palaeo-extension. This extension affected Carboniferous rocks on Belkov Island (Fig. 2f) and Palaeocene sediments on Bunge Land (Fig. 2e). However, it must be kept in mind that the normal faults on Belkov Island trend parallel to the fold axes and could therefore also represent crestal collapse related to folding.

The De Long Islands show a similar pattern to the Anjou and Lyakhov Islands. Strike-slip fault data from Henrietta Island yield evidence of a NE-SW-palaeocontraction. In Neogene volcanic rocks on Zhokov Island (Fig. 4b), small WNW-ESE-trending conjugate normal faults have developed (Fig. 4a) that fit into the extensional regime derived from fault-slip data on Belkov Island and Bunge Land (Fig. 4b).

\section{5.a. Limitations and uncertainties}

Deriving palaeostress data from fault-slip data has certain limitations, but its reliability is beyond doubt (Lacombe, 2012). In this study the greatest uncertainties arise from the limited data set. The outcrops are small and isolated. In some areas, only a few fault planes with striations are exposed (e.g. on Belkov and Kotel'ny Islands), whereas on Stolbovoy Island for example many faults planes with striations have developed. Nevertheless, the prominent NE-SW-palaeoshortening can also be confirmed on the basis of fold axes, indicating that the fault-slip data are reliable. Datasets on the extensional structures are also limited, but the derived palaeo-extension direction fits to the trend of normal faults observed on seismic lines (e.g. Drachev et al. 1998; Franke, Hinz \& Oncken, 2001; Franke \& Hinz, 2005, 2009).

\section{5.b. Timing of deformation}

To analyse the temporal evolution of the tectonic deformation, the different shortening and extension directions were tied to the stratigraphy of the region. The temporal resolution of the deformation phases remains limited however, due to the fact that many of the analysed outcrops are small and isolated. As a consequence of the restricted temporal resolution, only a preliminary deformation pattern can be derived. Horizontal palaeo-shortening affected all rocks older than Palaeocene throughout the New Siberian Islands. There is no evidence for contractional deformation in Palaeogene-Neogene rocks. The exposure on Novaya Sibir (Fig. 2c, d) indicates that WNW-ESE-trending reverse faults and the fault-related folds were offset by
WNW-ESE-trending normal faults. The extensional phase is therefore the youngest deformation phase affecting the area. Normal faults with the same trend as on Novaya Sibir were observed in late Neogene volcanic rocks on Zhokov Island, confirming that the extension is the youngest tectonic phase.

\section{5.c. Fracture analysis}

The fracture pattern analysis is difficult because of the limited exposure; fractures can only be approximately separated into pre-folding and syn-folding. The fractures in western Kotel'ny form an orthogonal pattern (Fig. 4a). The observed fracture pattern is most likely related to a pre-folding phase, comparable to the models developed by Bergbauer \& Pollard (2004) and Mynatt, Solomon \& Pollard (2009). In NW Kotel'ny fracture sets have developed on an anticlinal limb and enclose a low angle; there are small offsets visible along the individual fractures. Both fracture sets offset each other, which might imply that they were contemporaneously active. The model of Mynatt, Solomon \& Pollard (2009) provides a potential explanation for this fracture pattern. A pre-folding fracture set is reactivated during folding and a second new fracture set forms.

\section{Discussion}

Previous studies identified different tectonic phases on the New Siberian Islands. Kos'ko \& Korago (2009) described at least three deformation phases, ranging from a Caledonian shortening of the early Palaeozoic sedimentary rocks, followed by an Early Cretaceous tectonic phase (based on the observation of an unconformity below the Aptian-Albian deposits) and a phase of Cenozoic faulting. Kyz'michev et al. (2006) also observed a Jurassic-Cretaceous deformation phase based on syn-collisional sediments and attributed it to the closure of the Anyui Ocean.

Similarly, our structural dataset gives evidence for a polyphase tectonic deformation of the Laptev and East Siberian Sea area. We identified three palaeo-shortening directions (NE-SW, WNW-ESE and NNW-SSE to NNE-SSW) and one set of palaeoextensional directions (NE-SW to NNE-SSW). The NE-SE-directed shortening is the most prominent tectonic deformation. It can be observed on many of the New Siberian Islands and clearly dominates the study area (Fig. 4b). Evidence for this shortening direction is given by the trend of fold axes on Belkov and Kotel'ny Island and can be also derived on the basis of the faultslip data from Stolbovoy, Kotel'ny and Henrietta Islands (Fig. 4b). This shortening direction most likely reflects the fold belt formation (collisional stage) after the southwards-directed subduction of the Anyui Ocean (Fig. 5). On Bol'shoi Lyakhov Island, the shortening rotates into a more NNE-SSW direction. This fits with the local east-west trend of the South Anyui suture described by Kuzmichev (2009). Reverse faults and 

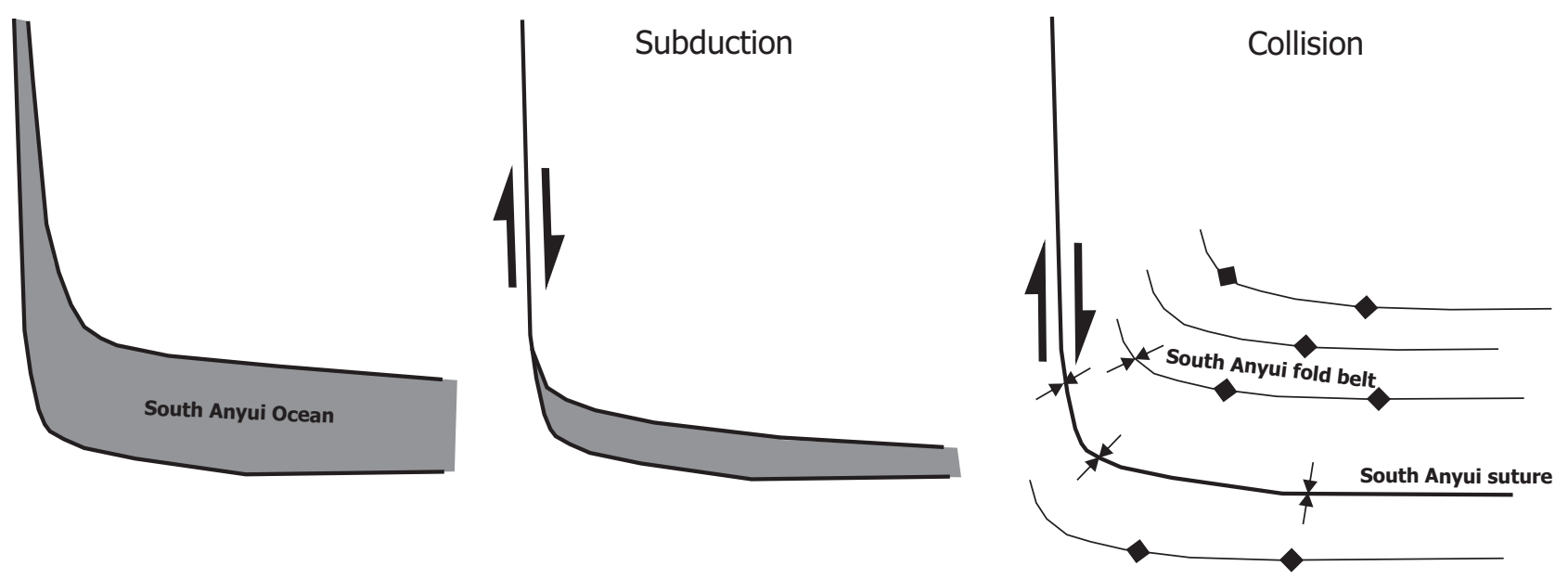

Figure 5. Schematic model for the closure of the South Anyui Ocean.

thrusts on Bol'shoi Lyakhov Island give also evidence for a WNW-ESE shortening (Fig. 4b).

Although the tectonic fabrics are very distinct it is difficult to temporally separate the palaeo-shortening directions; it is therefore difficult to decide whether they represent clear individual tectonic phases, or simply belong to one tectonic event that caused different shortening directions. Verzhbitsky \& Khudoley (2010) conclude that the NE-SW shortening is the oldest phase followed by the WNW-ESE contraction, which they attribute to post-collisional movement. Our data show that the pattern of tectonic deformation directions is quite homogeneous over the New Siberian Islands, with common horizontal palaeo-shortening directions. This supports the findings of Vernikovsky et al. (2013a) who concluded, from the match of the palaeomagnetic directions between the territories of the Anjou and De Long archipelagos, a tectonic unity had been present at least since Early Ordovician time.

The South Anyui suture is an important structural element in the Russian Arctic. It forms the southern and western boundary of the Alaska-Chukotka microplate (Miller \& Verzhbitsky, 2009), but the exact westwards extent of the South Anyui suture zone is still under debate (Sokolov et al. 2009; Kuzmichev, 2009). Different scenarios have been discussed. Fujita et al. (1997) assume that the suture has a strong bend and shows a north-south trend between Bol'shoi Lyakhov and Faddeyev Islands. In contrast, Natal'in et al. (1999) propose that the suture splits into a WNWESE-trending branch that is exposed on Bol'shoi Lyakhov Island and a NNW-SSE-trending branch crossing Faddeyev Island. Rowley \& Lottes (1988) assume that the South Anyui suture zone runs east of the New Siberian Islands. Based on seismic reflection lines, Franke et al. (2008) suggested a bend in the South Anyui suture between Stolbovoy and Bol'shoi Lyakhov Islands. In their model, the suture trends WNWESE in the area of Bol'shoi Lyakhov Island and shifts into a more NNW-SSE-directed orientation between Stolbovoy and Kotel'ny Islands (Fig. 1). This model is supported by field data. Most outcrops on Belkov and
Kotel'ny indicate a NE-SW-directed palaeo-shortening (Fig. 4b). On Bol'shoi Lyakhov Island there is evidence for a NNE-SSW-oriented palaeo-shortening, which is roughly perpendicular to the trend of the South Anyui suture. This would fit with a bending of the suture from an east-west trend in the south of the archipelago into a NNW-SSE trend in the west. Palaeogeographic reconstructions of the evolution of the Arctic region imply that the western part of the South Anyui suture is a large strike-slip zone (Fig. 5; Shepard, Müller \& Seton, 2013). This is also consistent with the shortening direction in the western part of the study area.

What is the consequence for our still insufficient knowledge of the kinematics and history of the preTertiary opening of the Arctic Ocean Basin? Lawver \& Scotese (1990) discuss a variety of models for the origin of the Amerasia Basin. Among the numerous models there is a popular model that involves the opening of the Amerasia Basin by in situ seafloor spreading and anticlockwise rotation of the Arctic Alaska-ChukchiAncestral Plate away from Arctic Canada about a pivot point situated in northern Yukon. It is still unclear if only portions of or the entire Amerasia Basin opened along such a shear zone, but our data indicate that such a mechanism would at least be consistent with the geology of the New Siberian Islands. The main shear zone would have run from the Amerasia side of the Lomonosov Ridge onto the Laptev Sea shelf.

The WNW-ESE-oriented shortening direction is much more difficult to explain. As mentioned above, Verzhbitsky \& Khudoley (2010) attribute the WNWESE contraction to post-collisional movements. Another possibility is wrench-dominated transpressional deformation as per the model of Tikoff \& Teyssier (1994), but this would require a more NNE-SSW trend of the South Anyui suture west of Kotel'ny Island. A comparable contraction with a WNW vergence was observed in the Verkhoyanks fold-thrust belt between 150 and $120 \mathrm{Ma}$ (Konstantinovsky, 2007). This would fit with the contraction direction observed on the New Siberian Islands, and the WNW-ESE stress 
direction could be a far-field effect of deformation in the Verkhoyanks fold-thrust belt.

The extension (NE-SW to NNE-SSW, green arrows in Fig. 4b) observed on Belkov Island, Kotel'ny Island, Bunge Land, Novaya Sibir and Zhokov Island is clearly the youngest phase and most likely a consequence of rifting in the Laptev Sea. The extension fits the orientation of major normal faults of the Laptev Rift (Drachev et al. 1998; Franke, Hinz \& Oncken, 2001; Franke, Hinz \& Reichert, 2004; Franke \& Hinz, 2005). The extensional direction derived from the fault-slip inversion can be also confirmed on the basis of recent earthquake focal mechanisms shown in Franke, Krüger \& Klinge (2000) and Gaina, Roest \& Müller (2002) (Fig. 4b). Some of these focal mechanisms provide evidence of locally pronounced strike-slip movements.

\section{Conclusions}

The New Siberian Islands are affected by different tectonic phases, three palaeo-shortening directions (NESW, WNW-ESE and NNW-SSE to NNE-SSW) and one palaeo-extension direction (NE-SW to NNESSW). All observed phases are Mesozoic-Cenozoic in age. The horizontal shortening is related to the closure of the South Anyui Ocean. The NE-SW-oriented palaeo-shortening is the most prominent tectonic direction in the study area and reflects the fold-thrust belt formation during the collision. The WNW-ESE and the NNE-SSW- to NNW-SSE-oriented palaeo-shortening directions are likely also a consequence of the formation of the South Anyui fold belt. The NNE-SSWto NNW-SSE-directed contraction could have been the result of the bend in the suture zone and the related along-strike changes in shortening direction. The last tectonic phase was extensional. Normal faults, developed in relatively unconsolidated (Cenozoic) sediments, indicate that the extension was younger than the shortening phases and was probably related to the evolution of the Laptev Sea Rift. This extensional phase extended towards the northeast and is also visible in brittle fabrics developed in young volcanic rocks on Zhokov Island.

Acknowledgements. P. Sobolev and T. Tolmasheva (VSEGEI, St Petersburg) are thanked for logistics and scientific support. The BGR is gratefully acknowledged for financial support. The BMBF/German Federal Ministry of Education and Research (Internationales Büro des BMBF) is gratefully acknowledged for financial supporting C. Brandes (RUS 11/A09). Finally, we thank O. Lacombe and H. Lorenz for constructive reviews.

\section{References}

Amrouch, K., Lacombe, O., Bellahsen, N., Daniel, J.M. \& CALlOT, J.-P. 2010. Stress and strain patterns, kinematics and deformation mechanisms in a basementcored anticline: Sheep Mountain Anticline, Wyoming. Tectonics 29, TC1005, doi: 10.1029/2009TC002525.
ANGELIER, J. \& MeChleR, P. 1977. Sur une méthode graphique de recherche des constraintes principales également utilisable en tectonique et en séismologie : la méthode des dièdres droits. Bulletin de la Societé Géologique de France 7, 1309-18.

BeAudoin, N., BellahSEN, N., LACOMBE, O.\& EMMANUEL, L. 2011. Fracture-controlled paleohydrogeology in a basement-cored, fault-related fold: sheep Mountain Anticline, Wyoming. United States. Geochemistry, Geophysics, Geosystems 12, doi: 10.1029/2010GC003494.

BeAUdoin, N., LACOMBE, O., BellahSEN, N. \& EMMANUEL, L. 2013. Contribution of studies of sub-seismic fracture populations to paleo-hydrological reconstructions (Bighorn Basin, USA). Procedia Earth and Planetary Science, Water Rock Interaction 14, 7, 57-60, doi: 10.1016/j.proeps.2013.03.198.

BeAudoin, N., LePretre, R., Bellahsen, N., LACOMBE, O., AMrouch, K., CALlot, J.-P., EMmanUel, L. \& DANiEL, J.-M. 2012. Structural and mircostructural evolution of the Rattlesnake Mountain Anticline (Wyoming, USA): New insights into the Sevier and Laramide orogenic stress build-up in the Bighorn Basin. Tectonophysics 576-577, 20-45.

Bellahsen, N., Fiore, P. \& Pollard, D. D. 2006. The role of fractures in the structural interpretation of Sheep Mountain Anticline, Wyoming. Journal of Structural Geology 28, 850-67.

Bergbauter, S. \& Pollard, D. D. 2004. A new conceptual fold-fracture model including prefolding joints, based on the Emigrant Gap anticline, Wyoming. GSA Bulletin 116, 294-307.

BergheMER, H. 1990. Grundlagen der Geophysik. Darmstadt: Wissenschaftliche Buchgesellschaft, $201 \mathrm{pp.}$

Bogdanovskit, O. G., Mineev, S. D., Assonov, S. S., SilantyeV, S. A., KarpenKo, S. F., ShuKolyukov, Yu. A. \& SAvostin, L. A. 1992. Magmatism on the De Long Islands, eastern Arctic: isotopic geochemistry and geochronology. Geokhimiya 1, 47-57.

Bondarenko, G. E., Soloviev, A. V., Tuchkova, M. I., GARVER, J. I. \& Podgornyi, I. I. 2003. Age of detrital zircons from sandstones of the Mesozoic flysch formation in the South Anyui Suture Zone (western Chukotka). Lithology and Mineral Resources 38, 16276.

CRAMER, B. \& FrANKe, D. 2005. Indications for an active petroleum system in the Laptev Sea, NE Siberia. Journal of Petroleum Geology 28, 369-84.

Delvaux, D., Moeys, R., Stapel, G., Petit, C., Levi, K., Miroshnichenko, A., Ruzhich, V. \& SAN'KOV, V. 1997. Paleostress reconstructions and geodynamics of the Baikal region Central Asia, Part 2. Cenozoic rifting. Tectonophysics 282, 1-38.

DRACHEV, S. S. 2011. Tectonic setting, structure and petroleum geology of the Siberian Arctic offshore sedimentary basins. In Arctic Petroleum Geology (eds A. M. Spencer, A. F. Embry, D. L. Gautier, A. V. Stoupakova \& K. Sorensen), pp. 369-94. Geological Society of London, Memoir no. 35.

DracheV, S. S., SAVOStin, L. A., GRoshev, V. G. \& BRUNI, I. N. 1998. Structure and geology of the continental shelf of the Laptev Sea, Eastern Russian Arctic. Tectonophysics 298, 357-93.

Dusseault, M. B., Maury, V., SAnfilippo, F. \& SANTARELLI, F. J. 2004. Drilling around salt: stresses, risks uncertainties. In Gulf Rocks 2004, 6th North America Rock Mechanics Symposium (NARMS), Houston, Texas, June 5-9, 2004. American Rock Mechanics Association Paper 04-647, 12 pp. 
ENGELDER, T. \& GEISER, P. 1980. On the use of regional joint sets as trajectories of paleostress fields during the development of the Appalachian Plateau, New York. Journal of Geophysical Research 85 B11, 6319-41.

Fischer, M. P. \& WilKerson, M. S. 2000. Predicting the orientation of joints from fold shape: results of pseudo-three-dimensional modeling and curvature analysis. Geology 28, 15-8.

FrANKE, D. \& HiNZ, K. 2005. The structural style of sedimentary basins on the shelves of the Laptev Sea and western East Siberian Sea, Siberian Arctic. Journal of Petroleum Geology 28, 269-86.

Franke, D. \& HinZ, K. 2009. Geology of the shelves surrounding the New Siberian Islands, Russian Arctic. Stephan Mueller Special Publication Series 4, 3544.

Franke, D., Hinz, K., Block, M., Drachev, S. S., Neben, S., Kos'Ko, M. K., ReICHERT, C. \& RoESER, H. A. 1998 (published 2000). Tectonics of the Laptev Sea region in north-eastern Siberia. In ICAM III: International Conference on Arctic Margins. Alfred-Wegener-Institute for Polar and Marine Research and the German Society of Polar Research, Celle (eds N. W. Roland and F. Tessensohn), pp. 51-58.

Franke, D., HINZ, K. \& ONCKEN, O. 2001. The Laptev Sea Rift. Marine and Petroleum Geology 18, 1083-127.

FranKe, D., HinZ, K. \& REICHERT, C. 2004. Geology of the East Siberian Sea, Russian Arctic, from seismic images: structures, evolution, and implications for the evolution of the Arctic Ocean Basin. Journal of Geophysical Research 109, B07106, doi: 10.1029/2003JB002687.

Franke, D., KrÜGER, F. \& KLINGE, K. 2000. Tectonics of the Laptev Sea Moma 'Rift' region: investigation with seismological broadband data. Journal of Seismology 4, 99-116.

Franke, D., ReIChert, C., DAMM, V. \& PiepJohn, K. 2008. The South Anyui suture, Northeast Arctic Russia, revealed by offshore seismic data. Norwegian Journal of Geology 88, 189-200.

FujtTA, K., CAMBRAY, F. W. \& Velbel, M. A. 1990. Tectonics of the Laptev Sea and Moma Rift systems, northeastern USSR. Marine Geology 93, 95-118.

Fujita, K., Stone, D. V., LAYER, P. W., PARfenov, L. M. \& Kos'MIN, B. M. 1997. Cooperative program helps decipher tectonics of northeastern Russia. Eos 24, 252 3.

Gaina, C., Roest, W. R. \& Müller, R. D. 2002. Late Cretaceous-Cenozoic deformation of northeast Asia. Earth and Planetary Science Letters 197, 273-86.

Gohram, F. D., Woodward, L. A., CAllender, J. F. \& GREER, A. R. 1979. Fractures in Cretaceous rocks from selected areas of the San Juan basin, New Mexico: exploration implications. AAPG Bulletin 64, 598-607.

HANCOCK, P. L. 1985. Brittle microtectonics: principles and practice. Journal of Structural Geology 7, 437-57.

HANCOCK, P. L. \& KADHI, T. 1978. Analysis of mesoscopic fractures in the Dhruma-Nisah segment of the central Arabian graben system. Journal of the Geological Society of London 135, 339-47.

HARRIS, J. F., TAYLOR, G. L. \& WALPER, J. L. 1960. Relation of deformational fractures in sedimentary rocks to regional and local structures. AAPG Bulletin 44, 1853-73.

HenNings, P. H., Olson, J. E. \& Thompson, L. B. 2000. Combining outcrop data and three-dimensional structural models to characterizes fractured reservoirs: an example from Wyoming. AAPG Bulletin 84, 830-49.

HERMAN, A. B. \& SPICER, R. A. 2010. Mid-Cretaceous floras and climate of the Russian high Arctic (Novosibirsk
Islands, Northern Yakutiya). Paleogeography, Paleoclimatology, Paleoecology 295, 409-22.

Homberg, C., Hu, J.-C., Angelier, J., Bergerat, F. \& LACOMBE, O. 1997. Characterization of stress perturbations near major fault zones: insights from field studies (Jura Mountains) and numerical modelling. Journal of Structural Geology 19, 703-18.

JONES, P. B. 1980. Evidence from Canada and Alaska on plate tectonic evolution of the Arctic Ocean Basin. Nature 285, 215-7.

Khain, V. E., Polyakova, I. D. \& Filtova, N. I. 2009 Tectonics and petroleum potential of the East Arctic province. Russian Geology and Geophysics 50, 334 45.

KONSTANTINOVSKY, A. A. 2007. Structure and geodynamics of the Verkhoyansk fold-and-thrust belt. Geotectonics 41, 337-54.

Kos'KO, M. \& KoraGO, E. 2009. Review of the geology of the New Siberian Islands between the Laptev and the East Siberian Seas, North East Russia. Stephan Mueller Special Publication Series 4, 45-64.

Kos'KO, M. K., LOPATIN, B. G. \& GANELIN, V. G. 1990. Major geological features of the islands of the East Siberian and Chukchi Seas and the northern coast of Chukotka. Marine Geology 93, 349-67.

Kos'Ko, M. K. \& Trufanov, G. V. 2002. Middle Cretaceous to Eopleistocene Sequences on the New Siberian Islands: an approach to interpret offshore seismic. Marine and Petroleum Geology 19, 901-19.

KuzmicheV, A. B. 2009. Where does the South Anyui suture go in the New Siberian Islands and Laptev Sea?: implications for Amerasia basin origin. Tectonophysics 463, 86-108

Kuzmichev, A. B., Aleksandrova, G. N. \& Herman, A. B. 2009. Aptian-Albian Coaliferous Sediments of Kotel'nyi Island (New Siberian Islands): New Data on the Section Structure and Ignimbrite Volcanism. Stratigraphy and Geological Correlation 17, 519-43.

KuzMicheV, A. B. \& PEASE, V. L. 2007. Siberian trap magmatism on the New Siberian Islands: constraints for Arctic Mesozoic plate tectonic reconstructions. Journal of the Geological Society 164, 959-68.

Kyz'michev, A. B., SolovieV, A. V., Gonikberg, V. E., SHAPIRO, M. N. \& ZAMZHITSKII, O. V. 2006. Mesozoic syncollisional siliciclastic sediments of the Bol'shoi Lyakhov island (New Siberian Islands). Stratigraphy and Geological Correlation 14, 30-48.

LACOMBE, O. 2012. Do fault slip data inversions actually yield 'paleostresses' that can be compared with contemporary stresses? A critical discussion. Geoscience, 344, 159-73, doi: 10.1016/j.crte.2012.01.006.

Lacombe, O., Bellahsen, N. \& Mouthereau, F. 2011. Fracture patterns in the Zagros Simply Folded Belt (Fras, Iran): constraints on early collisional tectonic history and role of basement faults. Geological Magazine 148, 940-63.

LAWver, L. A. \& Scotese, C. R. 1990. A review of tectonic models for the evolution of the Canada Basin. In The Arctic Ocean Region (eds A. Grantz, L. Johnson and J. F. Sweeney), pp. 593-617. Geological Society of America, Boulder, Colorado, Geology of North America no. 50.

LISLE, R. J. 1994. Detection of zones of abnormal strains in structures using Gaussian curvature analysis. $A A P G$ Bulletin 78, 1811-9.

MarretT, R. \& Allmendinger, R. W. 1990. Kinematic analysis of fault-slip data. Journal of Structural Geology 12, 973-86. 
Miller, E. L., Toro, J., Gehrels, G., Amato, J. M., Prokopiev, A., TuchKova, M. I., AKInIN, V. V., Dumitru, T. A., Moore, T. E. \& Cecile, M. P. 2006. New insights into Arctic paleogeography and tectonics from U-Pb detrital zircon geochronology. Tectonics $\mathbf{2 5}$, TC3013, doi: 1029/2005TC001830.

MiLler, E. L. \& VERZHBITSKY, V. E. 2009. Structural studies near Pevek, Russia: implications for formation of the East Siberian Shelf and Makarov Basin of the Arctic Ocean. Stephan Mueller Special Publications Series 4, 223-41.

Mynatt, I., Solomon, S. \& Pollard, D. D. 2009. Fracture initiation, development, and reactivation in folded sedimentary rocks at Raplee Ridge, UT. Journal of Structural Geology 31, 1100-13.

NARR, W. 1991. Fracture density in the deep subsurface: techniques with application to Point Arguello oil field. AAPG Bulletin 75, 1300-23.

NAtal'in, B. A., Amato, J. M., Toro, J. \& Wright, J. E. 1999. Paleozoic rocks of northern Chukotka Peninsula, Russian far east: implications for the tectonics of the Arctic region. Tectonics 18, 977-1003.

ROWLEY, D. B. \& LOTTES, A. L. 1988. Plate-kinematic reconstructions of the North Atlantic and Arctic: late Jurassic to Present. Tectonophysics 155, 73-120.

SAINTOT, A. \& ANGELIER, J. 2002. Tectonic paleostress fields and structural evolution of the NW-Caucasus fold-andthrust belt from Late Cretaceous to Quaternary. Tectonophysics 357, 1-31.

SATO, K. 2012. Fast multiple inversion for stress analysis from fault-slip data. Computers \& Geosciences 40, 1327.

Shepard, E. G., Müller, R. D. \& Seton, M. 2013. The tectonic evolution of the Arctic since Pangea breakup: Integrating constraints from surface geology and geophysics with mantle structure. Earth-Science Reviews 124, 148-83.

Silantyev, S. A., Bogdanovskit, O. G., Fedorov, P. I., KARPENKO, S. F. \& KostiTSYN, YU. A. 2004. Intraplate magmatism of the De Long Islands: A response to the propagation of the ultraslow-spreading Gakkel Ridge into the passive continental margin in the Laptev Sea. Russian Journal of Earth Sciences 6, 39-47.

Sokolov, S. D., Bondarenko, G. Ye., Layer, P. W. \& KRAVCHENKO-BEREZHNOY, I. R. 2009. South Anyui suture: tectono-stratigraphy, deformations, and principal tectonic events. Stephan Mueller Special Publications Series 4, 201-21.

STEARNS, D. W. \& FRIEDMAN, M. 1972. Reservoirs in fractured rock. In Stratigraphic Oil and Gas Fields: Classification, Exploration Methods, and Case Histories (ed. R.E. King), pp. 82-106. AAPG, Memoir no. 16.

TIKOFF, B. \& TEYSSIER, C. 1994. Strain modelling of displacement-field partitioning in transpressional orogens. Journal of Structural Geology 16, 1575-88.

Vernikovsky, V. A., Dobretsov, N. L. MEtelkin, D. V. Matushkin, \& N. YU. Koulakov, I. Yu. $2013 a$. Concerning tectonics and the tectonic evolution of the Arctic. Russian Geology and Geophysics 54, 838-58.

Vernikovsky, V. A., METELKIN, D. V. TOLMACHEVA, T. Yu. Malyshev, N. A. Petrov, O. V. Sobolev, \& N. N. MatushKIN, N. YU. 2013b. Concerning the issue of paleotectonic reconstructions in the Arctic and of the tectonic unity of the New Siberian Islands terrane: new paleomagnetic and paleontological data. Doklady Earth Sciences 451, Part 2, 791-7.

VerZHBITSKY, V. E. \& KHUdOLEY, A. K. 2010. The structural evolution and tectonic development of the Laptev Sea region in Mesozoic and Cenozoic. 72nd EAGE Conference \& Exhibition incorporating SPE EUROPEC 2010. Barcelona: EAGE.

YAMAJI, A. 2000. The multiple inverse method: a new technique to separate stresses from heterogeneous fault-slip data. Journal of Structural Geology 22, 441-52.

ZAHM, C. Z. \& HenNings, P. H. 2009. Complex fracture development related to stratigraphic architecture: Challenges for structural deformation prediction, Tensleep Sandstone at the Alcova anticline, Wyoming. AAPG Bulletin 93, 1427-46.

ZALOHAR, J. \& VRABEC, M. 2007. Paleostress analysis of heterogeneous fault-slip data: the Gauss method. Journal of Structural Geology 29, 1798-810. 